\title{
CHALLENGES IN GEOGRAPHY EDUCATION - A REVIEW OF RESEARCH PROBLEMS
}

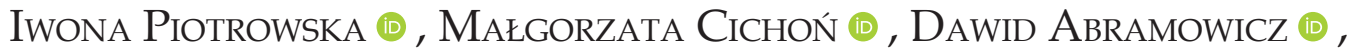 \\ JAKUB SYPNIEWSKI (D)
}

Department of Geography Didactics and Ecological Education, Faculty of Geographical and Geological Sciences, Adam Mickiewicz University in Poznań, Poland

Manuscript received: January 14, 2019

Revised version: February 10, 2019

Piotrowska I., Cichoń M., Abramowicz D., Sypniewski J., 2019. Challenges in geography education - a review of research problems. Quaestiones Geographicae 38(1), Bogucki Wydawnictwo Naukowe, Poznań, pp. 71-84. 2 figs, 2 tables.

AвSTRACT: Scientific research and student education aimed at preparing students to practice their profession under the conditions of civilization and technological changes play a special role in geography teaching. It is important to be aware of the impact of key competences which are necessary for every person to function in the modern world and are needed for self-fulfilment, personal development, social integration, flexible adaptation to any changes and which determine the success in adult life. Proper development of such skills contributes to the correct interpretation of natural and socio-economic phenomena and processes. The aim of the article is to present and discuss research work and teaching activities pursued by the Department of Geography Didactics and Ecological Education at the Faculty of Geographical and Geological Sciences of the Adam Mickiewicz University in Poznan, aimed at the use by students of various educational concepts and the resulting key competences necessary for their future work. Students also have the opportunity to develop soft competences, such as communication, courage of expression, self-esteem or responsibility for the group, to which employers have paid special attention in recent years. Therefore, comprehensive preparation of the student requires the implementation of specific educational concepts. The most important ones include bilingual education; CLIL, inquiry based science education (IBSE), project method, fieldwork, geographical educational trails, participation, as well as the use of geoinformation technologies, GIS and ICT.

KEY WORDS: didactics of geography, key competences, project method, geographical trails, fieldwork

Corresponding author: Iwona Piotrowska, ipiotrow@amu.edu.pl

\section{Introduction}

The beginnings of the development didactics of geography at the Poznan University can be traced back to Professor Stanisław Pawłowski (18821940; a student of Professor Eugeniusz Romer) and Professor Maria Czekańska (1902-1991). They both focused their scholarly and scientific interests on various aspects of geography, methodology and popular science. They noticed the importance of geography teaching in comprehensive scientific research and spent a lot of their time working in schools, writing geography textbooks and methodological guidelines for teachers (Piotrowska 1997, Kostrzewski, Piotrowska 2011, Piotrowska 2012a, b, 2018a). Their subsequent scholarly development, research and studies, as well as internal organizational changes (establishment of the Department of Geography Methodology, and later the Department of Regional Geography and 
Geography Didactics) raised the status of geography teaching in the university education of students and teachers. Presently, these activities are pursued by the Department of Geography Didactics and Ecological Education (DGDEE), established in 1999, which follows the long-standing didactic traditions of the Faculty of Geographical and Geological Sciences and the education of students preparing for the teaching profession (Piotrowska 2012a, b, Piotrowska, Cichoń 2015a).

In the scientific activity of DGDEE employees, the following works and research directions can be distinguished (Table 1, Piotrowska, Cichoń 2015a):

- about the current state and selected manifestations of geoecosystems functioning, geomorphological processes, changes in land use, tourist use of coastal zones, anthropogenic pressure, lake ecosystem services, landscape and cultural heritage,

- didactics of geography,

- dissemination of geographical knowledge among teachers and society.

The Department is involved in the preparation of school textbooks, methodological guidelines and in practical educational activities (Beczkiewicz, Piotrowska 2015, Kaczmarek et al. 2012), as well as in the development of core curriculum of geography in school education (Piotrowska et al. 2017, Szkurłat et al. 2017a, b, c). Cooperation of DGDEE staff with other departments of the Adam Mickiewicz University in Poznań in the implementation of educational projects financed by the European Union under the European Social Fund has made it possible to develop various educational concepts and test new didactic solutions. The Śniadecki College project resulted in the preparation of an innovative curriculum for teaching natural sciences, development of methodological assumptions of the Anticipative Education Strategy under the guidance of Prof. S. Dylak (Faculty of Educational Studies at the Adam Mickiewicz University), which was based on active involvement of students, emphasis on methods of independent learning in preparing for school classes in advance and the inclusion of information and communication technologies. The project resulted in the development of lesson plans, numerous methodological materials for the teacher and the preparation of educational films. As part of the eSchool-My Greater Poland project, a concept of nature education was developed with the use of the project method; at the same time broad substantive and methodological consultations were held and training for teachers was organized. The aim of the project Academy of Nature

Table 1. Research pursued by the Department of Geography Didactics and Ecological Education.

\begin{tabular}{|c|c|}
\hline Subject & Publications \\
\hline the process of teaching geography and nature & $\begin{array}{l}\text { Piotrowska 1999, 2000, 2010a, 2012d, h, 2014a, 2016, } \\
\text { Cichoń 2007, Cichoń, Piotrowska 2010a, b, 2015, 2016, } \\
\text { Cichoń, Rosik 2008, Piotrowska, Szkurłat } 2016\end{array}$ \\
\hline $\begin{array}{l}\text { inclusion of strategies, methods and techniques of teach- } \\
\text { ing geography and nature }\end{array}$ & $\begin{array}{l}\text { Piotrowska 2005a, 2008b, c, 2012c, Cichoń, Piotrowska } \\
\text { 2010b, Piotrowska 2014b, 2015a, b, c, Piotrowska, Cichoń } \\
\text { 2015b, Sypniewski 2015a, b, 2017a, b }\end{array}$ \\
\hline application of modern information technologies & Piotrowska 2010b, 2011b, c, Cichoń, Piotrowska 2017 \\
\hline application of technologies geoinformation & Piotrowska 2018b \\
\hline $\begin{array}{l}\text { application of the Geographic Information System in the } \\
\text { teaching of geography and nature }\end{array}$ & $\begin{array}{l}\text { Piotrowska 1996, Piotrowska 2018b, Szkurłat, Piotrowska } \\
2018\end{array}$ \\
\hline design and use of geographical educational trails & $\begin{array}{l}\text { Cichoń 2006, 2008d, 2009, Piotrowska, Cichoń 2012, Pio- } \\
\text { trowska, Cichoń 2016b, Abramowicz 2018a, b }\end{array}$ \\
\hline regional and ecological education & $\begin{array}{l}\text { Cichoń 2008a, b, c, Cichoń, Dybska-Jakóbkiewicz 2008, } \\
\text { Abramowicz 2018b }\end{array}$ \\
\hline $\begin{array}{l}\text { field classes and evaluation of the suitability of the land } \\
\text { for school fieldwork }\end{array}$ & Cichoń 2005, 2007, 2009, Cichoń, Piotrowska 2010a, b \\
\hline research in the field of developing key competences & $\begin{array}{l}\text { Cichoń, Piotrowska 2012, 2018, Piotrowska 2011a, Pio- } \\
\text { trowska, Cichoń 2015b }\end{array}$ \\
\hline $\begin{array}{l}\text { evaluation and assessment of the effectiveness of the } \\
\text { educational process }\end{array}$ & Piotrowska 2003 \\
\hline formative assessment & Cichoń, Piotrowska 2017 \\
\hline geographical bilingual education & $\begin{array}{l}\text { Piotrowska 2007, 2008a, b, 2009, 2011d, e, 2012e, f, g, h, } \\
2013\end{array}$ \\
\hline
\end{tabular}


Talents run in cooperation with the Institute for Agricultural and Forest Environment (IAFE) of the Polish Academy of Sciences in Poznan was to improve the quality of teaching science and nature awareness in upper secondary schools within the course of Landscape Ecology and to develop a concept and syllabus of ecological education using the project method and ICT technologies. Another project, Modern strategies of multilateral preparation of students for the teaching profession supported by the Internet educational system. Nature in school practice prepared students to teach nature at primary schools by introducing methodological innovations. The project Metropolitan Academy - local and regional education in the Poznan Metropolis run in cooperation with the Centre for Metropolitan Research of the Adam Mickiewicz University, addressed the issues of education in schools in the Poznan metropolis on the basis of scientific research. Creation of methodological concepts for the integration of ICT tools in nature education at different stages of school education with the use of new generation network services was the outcome of the Future ICT School Laboratory project run in cooperation with the Poznań Supercomputing and Networking Centre.

Didactics of geography developed presently is interdisciplinary in character; it draws from the latest results of research on geography as a science, psychology, pedagogy and general didactics, as well as neurodidactics. This approach gave rise to various scientific publications and elevated geography teaching to a higher rank, making it an interdisciplinary theoretical-practical science, which embraces many utilitarian aspects (Piotrowska, Cichoń 2015a). Geography teaching is also of particular importance in the process of preparing students for the teaching profession in a rapidly changing world. This means that in addition to the necessary knowledge of geographical sciences, the student should acquire and improve a wide variety of basic skills, called key competences. Key competences for lifelong learning are set out in the Recommendation of the European Parliament and of the Council of 22 May 2018 on key competences for lifelong learning and include:

- communication in the mother tongue,

- communication in foreign languages,

- mathematical competence and basic competences in science and technology,

- digital competence,
- learning to learn,

- social and civic competences,

- sense of initiative and entrepreneurship, and

- cultural awareness and expression.

Therefore, taking into account the premises presented above, the aim of the article is to present and discuss research work and teaching offered by the DGDEE aimed at helping students to use various educational concepts and the resulting key competences in their future work.

\section{Bilingual education}

Most societies in the world are bilingual and sometimes multilingual, so the introduction of bilingual teaching in educational systems was a natural step to prepare their representatives for communication. In Poland, bilingual teaching introduced in the 1991/1992 school year, initially in classes with French, was an example of innovation and educational challenge (Piotrowska 2008a, 2009, 2012g, Tab. 1). The basic objectives of bilingual teaching of geography include mastering substantive content in two languages on an equal level, the ability to collect and integrate knowledge necessary to describe and explain geographical phenomena and processes, acquiring competence in a foreign language sufficient to achieve bi-cultural and intercultural competence (Iluk 2000, Piotrowska 2008a, 2009, 2012g). Bilingualism consists in the alternative use of two language systems, mother tongue and foreign language at the same time, but to a different degree. In the Polish conditions, a kind of so-called subordinate bilingualism, called school bilingualism is dominant - it was introduced as a result of formal education and occurs outside the area where a foreign language is used (Dzięgielewska 2008). As a result, a new type of non-language teacher was created in the bilingual section, whose work requires a specific substantive and linguistic approach. At the beginning of the 1990s, there was a growing interest throughout the European Union in a variety of bilingual teaching in which integration, i.e. the teaching of subjects integrated with language learning, plays a key role. It is referred to as Content and Language Integrated Learning (CLIL), and treated as the main way of teaching a given discipline in a foreign language (Mentz 2008, Papaja 2008, 
Piotrowska 2012f). The aim of integrated content and language learning is to teach non-language subjects not in a foreign language, but together with and through a foreign language. This implies a more integrated approach to both teaching and learning. It is worth noting, however, that especially nowadays, in view of extensive migration possibilities when many people take up employment and settle in other countries, the issue of bilingualism, sometimes even multilingualism, is becoming extremely important in educational systems. An education system prepared for this purpose may help in various situations of tensions and conflicts arising precisely from cultural and ethnic differences (Piotrowska 2009).

Surveys conducted in 2008-2011 among geography teachers and students of Polish-French bilingual classes in Poland (Piotrowska 2008a, 2009, 2012f, g) revealed that the main reasons why students chose the bilingual class were: acquiring the ability to use a foreign language and vocabulary in various fields with particular emphasis on geography, getting to know French culture, participating in school exchange programmes, preparing to pass the International Baccalaureate in geography and the opportunity to study in other countries. Among the basic skills taught in this type of education were: using concepts in two languages, the ability to analyse geographical phenomena, the ability to construct explanations and definitions of phenomena in a foreign language, the use of French geographical vocabulary in practice, faster memorization of concepts by repeating them in two languages and the search for geographical information, e.g. on the Internet. Therefore, the process of preparing students for the role of teachers in bilingual classes is also a didactic challenge. Properly conducted education of students' results in higher linguistic and content competences, the possibility to participate in various types of programmes such as Erasmus and the teaching of attitudes to understand the geographical and cultural diversity of a particular language area.

\section{Inquiry Based Science Education (IBSE)}

Searching for answers to questions arising from cognitive curiosity related to everyday experiences is probably the only natural method of exploring the world. The most common problem faced by formal education in Poland is the fact that time constraints in school practice make it impossible for students to ask questions on their own, and if questions are asked, the search for answers becomes the domain of the teacher rather than the students who should formulate the questions. After all, a student who asks questions is more likely to start looking for answers to them or to perform tasks related to them than the one who does not reveal similar interests (Okon 1987). The same dilemmas in the discussion concerning the functioning of the school have been prevailing for many years. The initial widespread criticism of the so-called traditional school (started as early as in the 19th century) began to give way to the didactic concept of the new school (progressivist school). The sources of the philosophy of inquiry based learning, reaching back to the works of Piaget, Dewey, Vygotsky or Freire (Trna, Tranová 2012) can be traced to this period. In this sense, Inquiry Based Science Education (IBSE) refers to the constructivist ideas of these researchers, according to which it is the student himself who actively builds his knowledge and gives meaning to his own experience. Particularly noteworthy is the concept of psychologist J. S. Bruner, the so-called learning by discovery, which not only emphasized the independence of learning, but also the perception of relationships and regularities going beyond the available data (Kupisiewicz 1977). Although these ideas date back over 100 years, they are also a current area of interest for contemporary educationalists (Dylak 2013, Klus-Stańska 2010, and Spitzer 2011). Their research proves that our brains are not adapted to record information coming from outside, they were created to process it and create rules based on observed phenomena in the world around us (Hüther 2010, after Żylińska 2013).

Teaching inquiry is treated as a means to achieve an increase in competence, referred to in the American National Science Education Standards as scientific literacy, which, understood in a multi-faceted way, consists on the one hand in learning about the nature of science itself and its subject (with a special emphasis on physical life and earth sciences), and on the other hand in understanding the importance of its role in society and personal life. The work of NRC (1996) confirms that scientific literacy enables people to use scientific principles and processes in making personal 
decisions and to participate in discussions of scientific issues that affect society. A sound grounding in science strengthens many of the skills that people use every day, like solving problems creatively, thinking critically, working cooperatively in teams, using technology effectively, and valuing life-long learning. Provision of all citizens with both science literacy and positive attitude towards science is also highlighted in the European Commission's report, which recognises the importance of the competences developed by science education in, inter alia, everyday decision making and critical thinking (Rocard report 2007). Teaching is not about programming, but about problem-solving, not about giving answers, but about formulating questions, not about standardizing the views of students and educators, but about provoking young people to formulate their own thoughts (Nix 2016).

The educational process based on the IBSE strategy consists in seeking answers to the research questions posed. The results obtained in this way constitute a starting point for formulating more general conclusions (correctness and definitions). This type of education resembles a real research process conducted by scientists. Teaching according to the inquiry strategy takes place as long as students conduct their own analyses and draw conclusions themselves, including when research questions and data are provided to students from outside (Bell et al. 2005). There are seven phases of inquiry: introduction, exploration, designing the investigation, conducting the investigation, conclusion, presentation/communication, and deepening/broadening (Fig. 1).

Although the application of the IBSE strategy has become a domain of such school subjects as chemistry or biology, according to the authors of the Polish study entitled Basics of the IBSE methodology (Bernard et al. 2015) it is almost impossible for students to control the research process on

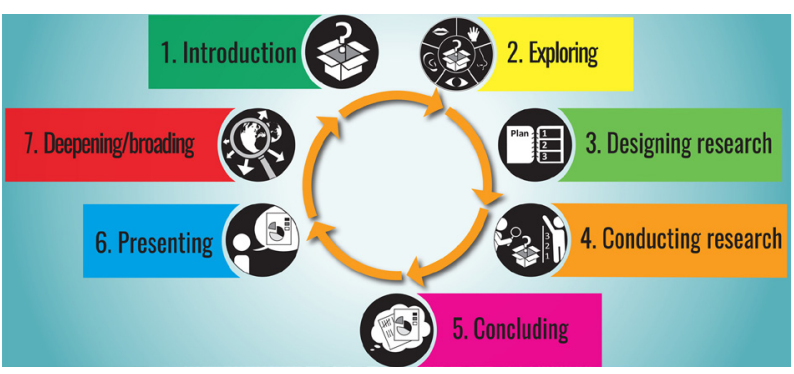

Fig. 1. The phases of inquiry-based learning (Van Uum et al. 2017). their own, from the moment the research problem is defined, in a Polish public school, e.g. during regular chemistry lessons. Another approach is presented by researchers who introduce open inquiry teaching as early as the primary school (Van Uum et al. 2017). In their opinion, the basic element of introducing the strategy is the knowledge of the IBSE by the teacher, who may decide to carry out inquiry education, or its elements, in a chosen and purposeful way during the classes he conducts.

IBSE can be implemented on one of four levels based on the activity of the student and teacher. The main criterion for the division is the amount of information provided by the teacher, which is presented in Table 2. The $\mathrm{X}$ mark indicates the information that students receive from the teacher at each level of inquiry (from confirmation to open inquiry).

Tasks stimulating the student's curiosity and making it possible to satisfy them increase the motivation to perform them (Błasiak 2011). A student's genuine curiosity can only be satisfied if the student has an influence on the content and forms of work, which in this case is a tool for searching for answers to questions that interest them. Teachers themselves, who work using elements of the IBSE, notice a number of benefits, including the effects of teaching in the form of knowledge and skills of students, achieving results, combining learning with fun, and finally transferring responsibility for the task to the student (Sypniewski 2015a). Despite this, the strategy is not popular among teachers of science subjects in schools in the Poznań agglomeration (including teachers of geography), which is confirmed by the fact that more than half of those participating in the survey have never heard of it (Sypniewski 2015a).

The DGDEE has for years made efforts to popularise teaching strategies through scientific inquiry in geographical education (Sypniewski 2015a, b, Sypniewski 2017a, b, Sypniewski 2018).

Table 2. Levels of inquiry (Bell et al. 2005).

\begin{tabular}{|l|c|c|c|}
\hline \multirow{2}{*}{ Level of inquiry } & \multicolumn{3}{|c|}{ Information given to students } \\
\cline { 2 - 4 } & question & methods & solution \\
\hline 1. confirmation & $\times$ & $\times$ & $\times$ \\
\hline 2. structured inquiry & $\times$ & $\times$ & \\
\hline 3. guided inquiry & $\times$ & & \\
\hline 4. open inquiry & & & \\
\hline
\end{tabular}


The most recent educational activity implemented at the Adam Mickiewicz University in Poznań is the project Kolaboratorium - a training programme for the region's inhabitants, within the framework of which, in 2019-2021, a series of workshops for teachers about the IBSE strategy Teaching through scientific inquiry for teachers of nature and geography - how to apply the IBSE strategy during lessons at school authored by MA Jakub Sypniewski will be conducted.

\section{Project method}

A project is a team, planned action of students, aimed at solving a specific problem (Regulation ... 2010). The main assumption of the project method is the independent work of students, and interest of students is the basis for all activities, in line with the assumption that no one should be forced to undertake unwanted activities. The second assumption of the project method is the subjectivity of the learner, the progressive role of the teacher, comprehensiveness and a departure from traditional assessment. The third, equally important issue of the project is the stage approach. The following stages are distinguished in the project: project preparation, project implementation, including collection, analysis, consultation and presentation of results and evaluation of results (Cichoń 2015a). For several years now, the project method has been applied anew in school practice at all levels of education. Despite the great variety of methodological solutions and topics, the same assumptions, stages of work and characteristics of the project as a hundred years ago are still valid.

The survey conducted among students of the Geography major at the Faculty of Geographical and Geological Sciences of the Adam Mickiewicz University shows how important is the presence and substantive and methodological support of the teacher. The less often the teacher meets the students, the worse the conditions for working on the project. Although it is supposed to be an independent work, the students expect help and attach great importance to it. The teacher should, on the one hand, encourage independence, but on the other hand check whether this autonomy brings results. It is most difficult to work in a project during the synthesis and final product preparation stage. However, special attention should be paid to this stage, because the conditions in which it is carried out will determine the development of the most important competences, such as inference, evaluation, problem-solving or the use of technology.

\section{Fieldwork}

When developing certain skills, each teacher should make a conscious choice of teaching methods. Particular importance is attached to field classes, the effectiveness of which, according to many authors (e.g. Nowacki 1994, Wojtkowicz 1999, Cichon 2009) is very high. Field classes are among the methodological proposals thanks to which teachers can not only achieve a high level of skills adjusted to the teaching content, but also by developing the research attitude of students, increase interest and durability of the acquired knowledge (Cichoń 2007). This was confirmed by a pedagogical experiment carried out by Cichon (2004, 2011b). It was found that the tasks related to the energy-dynamic sphere of surface waters enjoyed the greatest interest of students (Cichon 2006). Field activity of the students is also determined by the relief of the terrain and soil with vegetation. However, the influence of particular landscape components results mainly from the coexistence and specificity of the elements of natural and anthropogenic environment, which determine the attractiveness of the selected area (Cichon 2007).

Therefore, an effective process of perception is possible in areas of high geodiversity (Cichon $2007,2008)$. In the context of the experiment, the concept of geographical education in degraded areas may be of particular importance (Cichon 2009). According to this concept, anthropogenic objects, such as excavations or drainage ditches, also play a role as a means of illustration (Cichoń 2010). Urban areas may be an interesting place for conducting field activities. Contemporary youth is very much connected with urban areas, mainly represented by shopping centres. According to Cichon (2011c), it is a space where the needs of a given individual are optimally met, which is why shopping malls are positively perceived by young people. The revitalised production plants already belonging to the cultural heritage (Cichoń 2014) or facilities performing recreational and educational functions, e.g. in the Warta river valley (Cichon, 
Piotrowska 2015, Piotrowska, Cichoń 2016b), are also a source of great interest. On the other hand, human use of the geographical environment, including rocks, can be observed in public facilities or lapidaria (Cichon, Piotrowska 2010). The place for field activities is selected through field reconnaissance, where in the process of perception attention is paid to the structure of the landscape, stimuli and distinguishing features. Location of a site in a given place embraces not only the knowledge about a chosen place, but first of all a specific way of perceiving, shaping the appropriate course of thinking or the quantity and quality of incoming stimuli (Cichon 2009). It is also important to be able to shape pro-ecological attitudes at a given field site (Cichon 2010). A creative teacher should also pay attention to the possibility of safe and free cooperation of students. Properly prepared field stations deserve special attention (Piotrowska, Cichoń 2016a). By conducting observations and measurements supplemented by experiments, field stations enable the implementation of the concept of systemic and holistic approach to the geographical environment at the stage of analysis and cause-and-effect inference of quantitative and qualitative data collected in the field (Piotrowska, Cichon 2016a). It is also worth using mobile applications during field classes (Cichoń 2015b).

\section{Geographical educational trails in participatory activities}

Regional education and thus engaging students in active observation and understanding of processes and phenomena occurring in their immediate environment of residence, for many years has been an important issue in teaching geography and is one of the directions of research at the DGDEE. Within the framework of field classes, it is extremely valuable to use educational trails, the basic aim of which is to shape young people's attitude of respect towards the natural environment, deepen their knowledge and help them acquire skills and build a value system (Ciszewska 1990, Szleper 2002, Cichoń 2004, López de Haro, Segura Serrano 2013, Abramowicz 2018b). Moreover, the use of educational trails in geographical education enables the confrontation of geographical knowledge acquired at school with objects and processes occurring in nature (Kozak 2013). As Angiel (2016) points out, the educational trails make it possible to combine various approaches: complex, problematic, analytical and synthetic, as well as subjective and geographical-humanistic, focused on differences in the perception and feeling of the environment by the participants.

Due to the multifaceted perception of geographical trails, no clear definition of geographical trails has been defined yet. It is important that they should be always organized around interesting objects, ecosystems or captivating views, including natural and cultural elements (Ciszewska 1990, de la Vega 2004, Angiel 2006, Cichoń 2008, 2009, Piotrowska, Cichoń 2012, Piotrowska, Cichon 2016b). They are of an average length of 2 to $6 \mathrm{~km}$ and are marked out in the open air (Angiel 2006, Sławiński 2006).

Taking into account their form, they are usually of two kinds. According to Krzywańska (1999), educational trails can take the form of a walk in the field, during which, on the basis of an instruction prepared by the teacher, students perform tasks aimed at solving a specific problem. Prepared materials for students and appropriate methodological guides can be used many times (Adamczewska 2008). According to Kądziołka (1997), the educational trail consists of a conceptually determined route, along which there are stations with information boards, and their content is properly selected for teaching activities. De la Vega (2004) presented an interesting attempt at geographical definition of the educational trail, arguing that it is a motivating, valuable and useful teaching resource for the student to develop knowledge (it presents and consolidates the teaching contents) and leads to the assessment of the importance of the landscape (it generates attitudes and behaviours).

Co-creation of educational trails by different groups of citizens, including students, teachers, as well as residents and representatives of local authorities, is a relatively new phenomenon (López Fernández et al. 2017, Abramowicz 2018a). Such activities were undertaken, among others, in one of the schools in Córdoba (Spain) and consisted of classes with a small number of students held both in the classroom and in the field, and their main objective was to design a geographical educational trail in the city. The design process involved mainly students and teachers of the school (López 
Fernanandez et al. 2017). A similar example was the project implemented in the years 2015-2017 in Poznan, initiated in the DGDEE, the aim of which was to create a geographical educational trail with the participation of students, pupils and teachers of the primary school and representatives of the local community (Abramowicz 2018a, b). The project was completed in 2017 with the installation of information boards and its main aim was to plan the content of the information boards and their deployment in the field. The presented activities are examples of public participation, especially co-creation (co-production) of educational services (Porter 2013, ORE 2014, Abramowicz 2018b). It is worth noting that local communities participating in the creation of educational services evaluate educational trails as the most desirable forms of green areas development in the city (Stępniewska, Abramowicz 2016).

Despite the fact that the assumptions of social participation are increasingly used in the development of geographical space (Jankowski et al. 2018, Wójcicki 2018), it is worth applying them also in school geographical education. For this reason, engaging school communities in designing and creating geographical trails may contribute not only to increasing knowledge and skills among students, but also to building an attitude of responsibility for the nearest space, creating entrepreneurial behaviours, stimulating creativity, which in the long run may encourage students to become more involved in local matters.

\section{Geoinformation technologies, GIS and ICT}

Rapid technological development, unrestricted access of the society to digital devices and huge information resources, the possibility of using them and creating new ones, influence the transformation of people, including their operational skills and various competences (Tapscott 2009, Piotrowska 2011a). In particular, the development of digital systems and the introduction of Geographic Information Systems (GIS) have determined new possibilities of perceiving the world and conducting multidimensional analyses (Zwoliński 2009a, b). Such a situation makes it necessary to prepare young people accordingly. This preparation is the responsibility of the educational system, which should be monitored and adapted to civilizational changes. Therefore, from time to time it is necessary to modify it, because modern young people are more open to new technologies than their peers a few years ago, and since they belong to the digital generation they are characterized by high technological skills (Piotrowska 2011 b, c, Piotrowska 2018b). It is therefore expected that they will be educated and prepared for a variety of key skills and competences that will enable them to participate in an efficient functioning in society in the future. Geography is a predestined subject for better inclusion of information technologies in the education of future citizens who should be able to perceive, closely observe the natural environment and explain the processes taking place in the space (Piotrowska 2018b). A geographer using geoinformation collects, acquires, gathers, processes, transmits, analyses and interprets geospatial data (Zwoliński 2010). Such skills can be taught at the basic level in a school, where the student, through the freedom to use digital devices with greater interest, deepens his or her geographical knowledge.

Therefore, the obligatory introduction of GIS and GIS related issues to the core curriculum of geography at school level helps to offer education adapted to the civilizational and technological development of the 21st century. The use of digital technologies creates an opportunity to shape and improve digital competences and to include them in the scope of geographical education. It contributes to the development of computational thinking in solving problems. At the same time, an opportunity for geographical education in a virtual environment is created, which, of course, should not replace direct cognition in the field, in a geographical environment. The use of geoinformation technologies makes learning about distant regions much easier. On the other hand, the ability to create 3D visualizations improves the visual approach, effectiveness and efficiency of teaching geography in connection with its attractiveness. Including digital technology in geography may strengthen its potential as a school subject and increase the belief that it is useful in life (Piotrowska 2018, Szkurłat, Piotrowska 2018).

The use of Information and Communication Technologies (ICT) or multimedia in the teaching of geography is certainly no longer a challenge for today's geography teacher. The use of film or animation in geography lessons is a basic and commonly used tool (Piotrowska, Cichoń 
2015b). According to Cichoń (2015), a good teacher working with traditional methods and ICT may not be good enough to ensure effective education. The student of the so-called $Z$ generation needs a teacher who will be able to work with the use of generally available, modern (and natural for the student) devices, software and the Internet, therefore the core curriculum clearly indicates the necessity of using GIS. Since technologies accompany us in everyday life and confirm their usefulness, they must also be included in the education and development of students. This is not about a complete revolution, but rather more practical education. According to Głowacz (2015), however, no programme solutions can be effective without changing the thinking of geography teachers. According to Polak (2014), teachers cannot be forced, but rather encouraged to use simple tools, learn from students and invest time in the preparation of digital materials.

\section{Using key competences in future work}

The study of Cichoń and Piotrowska (2017) argues that graduates of geography can be better perceived on the labour market than graduates of other majors, because studying such a diverse scientific discipline provides a basis not only for the development of logical thinking, but also for flexibility and adaptation to cognition and understanding of changes taking place in the natural and socio-economic environment. Graduates also have a global, international perspective on the economy. A professional geographer, regardless of specialization, is characterized by high competence in the field methods and spatial thinking. The combination of knowledge about the natural environment with sustainable development and GIS, gives graduates of geography the basis for a good start on the labour market. Cichon and Piotrowska (2017) also draw attention to the results obtained by students during their studies in general academic fields and within the framework of the Educational Module. The level of competence is higher in the group of students preparing for the teaching profession. On the basis of observations and interviews with students and employers, it can be concluded that students graduating from the Educational Module are more likely to find employment. More often than graduates without didactic preparation, they manage projects

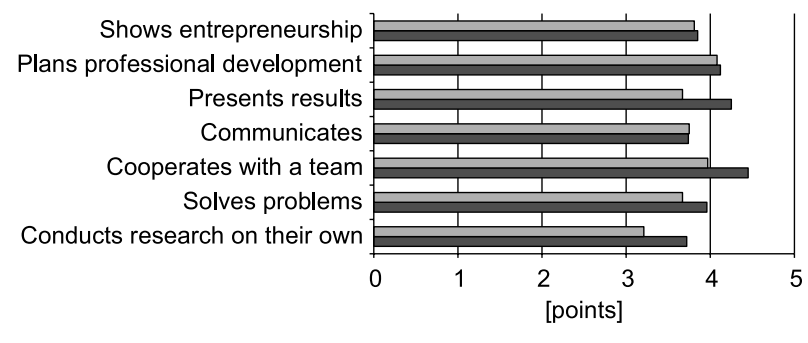

- a general geographical profile with the didactic module

Fig. 2. Assessment of the level of didactic competencies of students of the last year of master's studies of a study conducted by Cichoń and Piotrowska (2018).

and small teams, as confirmed by earlier studies conducted by Piróg, Piróg (2007) and Gierańczyk and Duży (2012). Cichoń and Piotrowska (2012) conducted a study among students of the Faculty of Geographical and Geological Sciences of the Adam Mickiewicz University and found that the combination of the project method, geographical essay and review is an effective strategy for developing key competences.

Competences developed through methods of self-acquisition of knowledge should be complemented by methods of knowledge assimilation and valuation. Combining different teaching methods increases the probability of developing different competences at a higher level (Fig. 2).

\section{Conclusion}

The scientific achievements of the Department of Geography Didactics and Ecological Education at the Adam Mickiewicz University in Poznan include various studies. Research interests in physical geography, socioeconomic geography and didactics of geography can be traced back to the traditions of the Poznań centre. The DGDEE also cooperates with other university geographic and didactic departments in Poland in the field of didactics of geography, and the effect of this cooperation of educators are annual conferences and the work of the Geographical Education Commission of the Polish Geographical Society.

For 20 years, the DGDEE has continued its research, particularly in the field of teaching methods, regional education or field classes. The staff, using the results of their own scientific research, deal with the issues of geographical educational trails, project method, IBSE strategy or public participation. They also develop issues that are 
considered valuable in world literature. These include such issues as neurodidactics, the use of eye-tracker, GIS or content-language integrated learning (CLIL). The research conducted at the DGDEE helps the staff to comprehensively prepare students for the profession of a geography teacher, and by developing key competences they increase their chances of finding a job also outside the school. The Department staff involved in various projects and initiatives, cooperating with, among others, the Ministry of Education, the Board of Education, Publishers, and Associations, show students many opportunities to use their knowledge and geographical skills and find their place in various professions. Scientific research and educational activities cover not only the academic environment, but are also directly related to educational institutions, local government units and the local community. That is why the DGDEE has participated in many popular science events, promoting and disseminating the results of its research presented in over 300 different publications. On the other hand, through the participation in international conferences represents the community of geography educators and implement new educational strategies on an ongoing basis, without giving up our own concepts and teaching experiments. At the same time, it is worth noting the contribution of Poznan didactics in the development of geography didactics in Poland. Some of the research directions listed in the introduction are the most developed in Poznań, while others are just developed.

\section{Acknowledgments}

Thank you very much to the reviewers for valuable comments and suggestions that improved the paper.

\section{Authors' contribution}

All authors evenly participated in the creation of the article, 25 percent each.

\section{References}

Abramowicz D., 2018a. La coproducción de servicios educativos como una premisa para involucrar a las comunidades locales en el proceso de creación de itinerarios didácticos geográficos. XII Congreso de Didáctica de la Geografía, Madrid. El Libro de Resúmenes.
Abramowicz D., 2018b. Innowacyjny przykład wytyczania ścieżek dydaktycznych z udziałem społeczności lokalnej na przykładzie geograficznej i przyrodniczej ścieżki dydaktycznej na Szachtach w Poznaniu. Prace Komisji Edukacji Geograficznej PTG 8: 219-231.

Adamczewska M., 2008. Rola obszarów przyrodniczo cennych $w$ edukacji geograficznej na przykładzie województwa łódzkiego. In: R. Wiśniewski, W. Gierańczyk (eds.), Geografia we wspótczesnym systemie kształcenia. Dokumentacja Geograficzna 38: 18-23.

Angiel J., 2006. The role of didactic trails in geographical education in Poland. Miscellanea Geographica 12: 277-286.

Angiel J., 2016. W poszukiwaniu świata wartości poprzez geograficzne okulary. Zeszyty Naukowe Wyższej Szkoty Humanitas, Pedagogika 12: 33-43.

Beczkiewicz M., Piotrowska I., 2015. Wstęp. Założenia programu nauczania przedmiotu Ekologii Krajobrazu; Technologia informacyjno-komunikacyjna $\mathrm{w}$ przedmiocie ekologia krajobrazu; "Nakładka” dla ucznia zdolnego - Akademia Talentów Przyrodniczych (ATP). In: M. Beczkiewicz, M. Szyszkiewicz-Golis (eds.), Ekologia Krajobrazu. Cz. 2. Przewodnik metodyczny. IBŚRiL, PAN, Poznań: 6-22.

Bell R.L., Smetana L., Binns I., 2005. Simplifying inquiry instruction. The Science Teacher 72(7): 30-33.

Bernard P., Białas A., Broś P., Ellermeijer T., Kędzierska E., Krzeczkowska M., Maciejowska I., Odrowąż E., Szostak E., 2013. Podstawy metodologii IBSE. In: I. Maciejowska, E. Odrowąż (eds.), Nauczenie przedmiotów przyrodniczych kształtujące postawy i umiejętności badawcze uczniów. Uniwersytet Jagielloński, Kraków: 9-17.

Błasiak W., 2011. Rozważania o nauczaniu przyrody. Wydawnictwo Naukowe Uniwersytetu Pedagogicznego, Kraków.

Cichoń M., 2004. Zajęcia terenowe w edukacji geograficznej i regionalnej. MS, Poznań, Biblioteka Uniwersytetu im. Adama Mickiewicza.

Cichoń M., 2006. Geograficzne ścieżki dydaktyczne warunkiem prawidłowego postrzegania i zrozumienia krajobrazu. In: T. Komornicki, Z. Podgórski (eds.), Idee $i$ praktyczny uniwersalizm geografii. Dokumentacja Geograficzna 33: 302-307.

Cichoń M., 2007. Pattern and environmental determinants of perception during experimental fieldwork in different landscape conditions. In: K. Donert, P. Charzyński, Z. Podgórski (eds.), Teaching geography in and about Europe. Geography in European higher education, Herodot Network \& Association of Polish Adult Educators 4: 44-49.

Cichoń M., 2008. Postrzeganie krajobrazu na geograficznych ścieżkach dydaktycznych. Przegląd Geograficzny 80(3): 443-459.

Cichoń M., 2009. Ocena i wybór terenu w projektowaniu geograficznych ścieżek dydaktycznych. Geografia w szkole 1: 28-34.

Cichoń M., 2010. The Gosławice as an example of an object attractive and useful for fieldwork in degraded area. In: P. Charzyński, K. Donert, Z. Podgórski (eds.), Geography in European higher education. Fieldwork in Geography bilingual teaching, Herodot Network \& Association of Polish Adult Educators 14: 97-105.

Cichoń M., 2011a. Results of systemic transformation in geography education. Prace i Studia Geograficzne 48: 113-124.

Cichoń M., 2011b. Efektywność zajęć terenowych a kształtowanie umiejętności jako przyczynek do dyskusji na temat poziomu nauczania $w$ warunkach wzrastających oczekiwań społecznych. Kwartalnik Pedagogiczny 3: 119-132. 
Cichoń M., 2011c. Valuation of contemporary urban space by youth (the Poznan case study). In: K. Donert, P. Charzyński, Z. Podgórski (eds.), Exploring human Geography - bilingual approach. Geography in European higher education, Herodot Network \& Association of Polish Adult Educators 15: 135-142.

Cichoń M., 2014. Teaching Geography and History based on the industrial heritage issues. In: P. Charzyński, K. Donert, Z. Podgórski (eds.), Tools for cross-curricular education in bilingual Geography and History. Geography in European higher education, Herodot Network \& Association of Polish Adult Educators 18: 144-151.

Cichoń M., 2015a. Metoda projektu edukacyjnego. In: M. Beczkiewicz, M. Szyszkiewicz-Golis (eds.), Ekologia Krajobrazu cz. II. Przewodnik metodyczny. IŚRiL PAN, Poznań: 38-47.

Cichoń M., 2015b. The use of selected mobile applications for geography fieldwork. In: P. Charzyński, K. Donert, Z. Podgórski (eds.), Mapping the world - spatial skills in bilingual education. Geography in European higher education, Herodot Network \& Association of Polish Adult Educators 20: 158-166.

Cichon M., 2017. Ecosystem services of the selected Polish lakes in geographical education. In: P. Charzyński, K. Donert, Z. Podgórski (eds.), UN's sustainable development goals - teach them bilingually. Geography in European higher education, Herodot Network \& Association of Polish Adult Educators 21: 100-107.

Cichoń M., Dybska-Jakóbkiewicz I., 2008. Koncepcja nauczania o własnym regionie $\mathrm{w}$ przestrzeni miejskiej. Prace i Studia Geograficzne 39: 43-50.

Cichoń M., Piotrowska I., 2010a. Role of geographical field classes in the formation of the skills of observation and identification of rocks. In: P. Charzyński, K. Donert, Z. Podgórski (eds.), Fieldwork in Geography bilingual teaching. Geography in European higher education, Herodot Network \& Association of Polish Adult Educators 14: 106-116.

Cichoń M., Piotrowska I., 2010b. Zajęcia terenowe w mieście $\mathrm{i}$ ich rola $\mathrm{w}$ procesie kształtowania umiejętności obserwacji i rozpoznawania skał (na przykładzie miasta Poznania). In: S. Liszewski (ed.), Obszary metropolitalne we wspótczesnym środowisku geograficznym. Łódź 1: 366-376.

Cichoń M., Piotrowska I., 2012. Kształtowanie kompetencji kluczowych wśród studentów geografii poprzez metodę projektu, esej geograficzny i recenzję. In: Z. Podgórski, E. Szkurłat (eds.), Wybrane problemy akademickiej i szkolnej edukacji geograficznej. Prace Komisji Edukacji Geograficznej PTG 2: 151-168.

Cichoń M., Piotrowska I., 2015. Fieldwork in the Warta valley: a new teaching concept. In: P. Charzyński, K. Donert, Z. Podgórski (eds.), On the Vistula banks - fieldwork in bilingual education. Geography in European higher education. EUROGEO \& Association of SOP Oświatowiec, Torun 19: 112-121.

Cichoń. M., Piotrowska I., 2016. Neurodydaktyka w procesie kształcenia geograficznego. In: I. Piotrowska, E. Szkurlat (eds.), Nowe problemy i metody badań procesu ksztatcenia geograficznego. Prace Komisji Edukacji Geograficznej PTG, 6: 97-112.

Cichoń M., Piotrowska I., 2017. Aplikacje interaktywne wspomagające proces oceniania kształtującego. In: J. Rodzoś, E. Szkurłat (eds.), Edukacja geograficzna wobec problemów wspótczesnego świata. Prace Komisji Edukacji Geograficznej PTG 7: 117-128.
Cichoń M., Piotrowska I., 2018. Level of academic and didactic competencies among students as a measure to evaluate geographical education and preparation of students for the demands of the modern labour market. Quaestiones Geographicae 37(1): 73-86, DOI: 10.2478/quageo-2018-0006.

Ciszewska H., 1990. Ścieżka dydaktyczna. In: A. Dylikowa (eds.), Dydaktyka geografii w szkole podstawowej. WSiP, Warszawa: 89-102.

de la Vega A.G., 2004. El itinerario geográfico como recurso didáctico para la valoración del paisaje. Didáctica Geográfica 6: 79-95.

Dylak S., 2013. Architektura wiedzy w szkole. Difin, Warszawa.

Dzięgielewska Z., 2008. Specyfika nauczania dwujęzycznego: techniki pracy na lekcjach języka i przedmiotów niejęzykowych. In: Z. Dzięgielewska (ed.), Nauczanie dwujęzyczne w Polsce i Europie. CODN, Warszawa: 34-38.

Gierańczyk W., Duży W., 2012. Zawód geograf - atrakcyjność studiów geograficznych a przydatność na rynku pracy (w opiniach studentów kierunku geografia na wydziale Biologii i Nauk o Ziemi UMK). In: Z. Podgórski, E. Szkurłat (eds.), Wybrane problemy akademickiej i szkolnej edukacji geograficznej. Prace Komisji Edukacji Geograficznej PTG 2: 113-134

Głowacz A., 2015. Teoretyczne i praktyczne aspekty wykorzystania GIS w szkolnej edukacji geograficznej. In: A. Hibszer, E. Szkurłat (eds.), Technologie informacyjno-komunikacyjne w geograficznej praktyce edukacyjnej. Prace Komisji Edukacji Geograficznej PTG 5: 73-98.

Iluk J., 2000. Nauczanie bilingwalne. Modele, koncepcje, założenia metodyczne. Wydawnictwo Uniwersytetu Sląskiego, Katowice.

Jankowski P., Kaczmarek T., Zwoliński Zb., Bąkowska-Wladmann E., Brudka C., Czepkiewicz M., Mikuła Ł., Młodkowski M., 2018. Zastosowanie aplikacji geoankiety $i$ geodyskusji w partycypacyjnym planowaniu przestrzennym - dobre praktyki. Bogucki Wydawnictwo Naukowe, Poznań.

Kaczmarek T., Piotrowska I., Cichoń M., 2012. Koncepcja interdyscyplinarnego projektu edukacyjnego dla gimnazjum pt: „Wiedza o Metropolii Poznań". Centrum Badań Metropolitalnych UAM, Poznań: 1-51.

Kądziołka J., 1997. Wycieczka szkolna. In: S. Piskorz (ed.), Zarys dydaktyki geografii. PWN, Warszawa.

Klus-Stańska D., 2010. Konstruowanie wiedzy w szkole. Wydawnictwo Uniwersytetu Warmińsko-Mazurskiego, Olsztyn.

Kostrzewski A., Piotrowska I., 2011. M. Czekańska, Morze Bałtyckie i dydaktyka geografii w badaniach geograficznych. Klasycy Nauki Poznańskiej, PTPN, Poznań, 53: 1-256.

Kozak A., 2013. Obszary chronione możliwością rozwoju turystyki edukacyjnej na przykładzie ścieżek przyrodniczo-edukacyjnych „Bużny Most” i „Nadbużańskiej Łęgi». Problemy Ekologii Krajobrazu. Rekreacja w krajobrazach o wysokim potencjale 34: 111-116.

Krzywańska J., 1999. Rodzaje zajęć terenowych In: R. Olaczek, A. Warcholińska (eds.), Ochrona środowiska i żywych zasobów przyrody. Uniwersytet Łódzki, Łódź.

Kupisiewicz Cz., 1977. Podstawy dydaktyki ogólnej. PWN, Warszawa.

López de Haro, F., Segura Serrano, J. A., 2013. Los itinerarios didácticos: un recurso interdisciplinar y vertebrador del currículum. Espiral, Cuadernos del Profesorado. Revista Digital del Centro de Profesorado Cuevas - Olula 6: 15-31. 
López Fernández J.A., Mora Márquez M., Arrebola Haro J. C., Medina Quintana S., 2017. Itinerarios didácticos interdisciplinares en el grado de educación primaria: Una propuesta en la ciudad de Córdoba. Enseñanza de las Ciencias Núm. extra: 1851-1856.

Mentz O., 2008. Models of bilingual education. In: K. Donert, P. Charzyński, Z. Podgórski (eds.), Bilingual Geography - aims, methods and challenges. Geography in European higher education, Herodot Network \& Association of Polish Adult Educators 5: 91-96.

NRC [National Research Council], 1996. National Science Education Standards, The National Academies Press, Washington, DC.

Nix Ch., 2016. Nauka stawiania pytań. Dialog 7-8(716-117): 126-130.

Nowacki T., 1994. Aktywizujące metody w ksztatceniu. Wydawnictwo CDN., Pracownia Doskonalenia Nauczycieli Przedmiotów Zawodowych, Warszawa: 34.

Okoń W., 1987. Nauczanie problemowe we wspótczesnej szkole. Wydawnictwa Szkolne i Pedagogiczne, Warszawa.

ORE [Ośrodek Rozwoju Edukacji], 2014. Partycypacja a lokalna polityka oświatowa - raport z badań terenowych. Warszawa.

Papaja K., 2008. Content and Language Integrated Learning In Geography. In: K. Donert, P. Charzyński, Z. Podgórski (eds.), Bilingual Geography - aims, methods and challenges. Geography in European higher education. LiverpoolTorun, Herodot Network \& Association of Polish Adult Educators 5: 33-41.

Piotrowska I., 1996. Wykorzystanie Geograficznych Systemów Informacyjnych w nauczaniu geografii. In: J. Jarowiecki, S. Piskorz (eds.), Różne drogi ksztatcenia i doksztatcania nauczycieli geografii. AP, Kraków: 136-143.

Piotrowska I., 1997. Profesor Maria Czekańska - geograf i nauczyciel. Czasopismo Geograficzne 1: 19-23.

Piotrowska I., 1999. Znaczenie praktyk szkolnych w przygotowaniu do zawodu nauczycielskiego studentów Wydziału Nauk Geograficznych i Geologicznych UAM. Biuletyn COMSN 13/14: 60-64.

Piotrowska I., 2000. Geografia a praktyka szkolna w nowym systemie edukacyjnym. In: Z. Zioło (ed.), Geografia w reformowanym systemie szkolnictwa. Nowoczesna Szkoła. Wydawnictwo Naukowe Akademii Pedagogicznej, Kraków, 3: 39-47.

Piotrowska I., 2003. Ewaluacja metod nauczania w edukacji geograficznej. In: M. Śmigielska, J. Słodczyk (eds.), Edukacja geograficzno-przyrodnicza $w$ dobie globalizacji i integracji europejskiej. Uniwersytet Opolski, Opole: 39-42.

Piotrowska I., 2005. Observation and presentation of phenomena in Geography education. In: K. Donert, P. Charzyński (eds.), Geography in European higher education. Changing horizons in geography education. Herodot Network \& Association of Polish Adult Educators 2: 52-57.

Piotrowska I., 2007. Cognitive and application aspects in the bilingual teaching of geography. In: K. Donert, P. Charzyński, Z. Podgórski (eds.), Geography in European higher education. Teaching Geography in and about Europe. Herodot Network \& Association of Polish Adult Educators 4: 50-57.

Piotrowska I., 2008a. Dwujęzyczne nauczanie geografii wyzwaniem edukacyjnym XXI wieku. Sosnowiec. In: A. Hibszer (ed.), Polska Dydaktyka Geografii - Idee, Tradycje, Wyzwania. WNOZ UŚ, Sosnowiec: 218-224.

Piotrowska I., 2008b. Methods of bilingual geography employing a film, a mind map and a poster. In: K. Donert, P. Charzyński, Z. Podgórski (eds.), Bilingual Geography
- aims, methods and challenges. Geography in European higher education. Herodot Network \& Association of Polish Adult Educators 5: 42-48.

Piotrowska I., 2008c. Jak nauczać i zainteresować geografią Polski wykorzystując metodę posteru. In: F. Plit (ed.), Dylematy nauczania geografii Polski. Prace i Studia Geograficzne 39: 93-99.

Piotrowska I., 2009. Wartości poznawcze i aplikacyjne geografii w nauczaniu dwujęzycznym. In: G. Janicki, M. Łanczont (eds.), Geografia $i$ Wartości. Wydawnictwo UMCS, Lublin: 156-162.

Piotrowska I., 2010a. Rola dydaktyki geografii w kształceniu twórczego nauczyciela. In: A. Kwatera, P. Cieśla (eds.), Rola $i$ zadania dydaktyk przedmiotowych w ksztatceniu nauczycieli. Uniwersytet Pedagogiczny, Kraków: 136-144.

Piotrowska I., 2010b. Nowoczesne technologie w nauczaniu o krajobrazie. Bogucki Wydawnictwo Naukowe, Poznań.

Piotrowska I., 2011a. Influence of education transformation on improving key competence in geography teaching. Prace i Studia Geograficzne 48: 27-40.

Piotrowska I., 2011b. Pokolenie cyfrowe w szkole XXI wieku. In: Pedagogia. Wydawnictwo NAKOM, Poznań 8: 45-49.

Piotrowska I., 2011c. Nowoczesne technologie multimedialne w dydaktyce nauk przyrodniczych. In: G. Słoń (ed.), Nowoczesne technologie $w$ dydaktyce. Wydawnictwo Politechniki Świętokrzyskiej, Kielce: 266-272.

Piotrowska I., 2011d. Fieldwork projects in bilingual geography teaching - orientation in geographical space. In: K. Donert, P. Charzyński, Z. Podgórski (eds.), Fieldwork in bilingual geography teaching. Geography in European higher education. EUROGEO \& Association of Polish Adult Educators 15: 115-125.

Piotrowska I., 2011e. Efekty dydaktyczne w dwujęzycznym nauczaniu geografii. In: M. Tracz, E. Szkurłat (eds.), Efekty ksztatcenia geograficznego na różnych poziomach edukacji. Prace Komisji Edukacji Geograficznej PTG 1: 99-111.

Piotrowska I., 2012a, Metodyka nauczania geografii (19511984); Dydaktyka geografii (1984-2010), Pracownia Dydaktyki Geografii i Edukacji Ekologicznej. In: Dzieje nauk geograficznych i geologicznych na Uniwersytecie w Poznaniu. Praca zbiorowa, t. 1: Historia, Poznań.

Piotrowska I., 2012b, Maria Czekańska (1902-1991). In: Dzieje nauk geograficznych i geologicznych na Uniwersytecie w Poznaniu. Praca zbiorowa, t. 2: Biografie, Poznań.

Piotrowska I., 2012c. Metoda projektu w naukach przyrodniczych. In: S. Dylak (ed.), Metoda projektów i jej konteksty w szkolnej edukacji przyrodniczej i matematycznej. Poznań: 27-31.

Piotrowska I., 2012d. Kształtowanie pojęć w naukach przyrodniczych. In: S. Dylak (ed.), Metoda projektów i jej konteksty w szkolnej edukacji przyrodniczej i matematycznej. Poznań: 46-50.

Piotrowska I., 2012e. Geography in Polish and French education systems - comparative study at the secondary school level. In: B. Wójtowicz (ed.), Natural sciences in educational systems of European countries in the 21 $1^{\text {st }}$ century. Wydawnictwo DEHON, Kraków: 51-62.

Piotrowska I., 2012f. Kształtowanie pojęć geomorfologicznych w dwujęzycznym nauczaniu geografii fizycznej. Studia i Prace z Geografii i Geologii 24: 1-187.

Piotrowska I., 2012g. Nauczanie dwujezyczne - historycznie $i$ praktycznie. Pedagogia. Wydawnictwo NAKOM, Poznań: 38-44.

Piotrowska I., 2012h. The didactic model LdL (Lernen durch Lehren; Learning by Teaching) as way to learn in region- 
al Geography. In: K. Donert, P. Charzyński, Z. Podgórski (eds.), Bilingual teaching - globalization, regional geography and english integration. Geography in European higher education. EUROGEO \& Association of Polish Adult Educators 16: 120-125.

Piotrowska I., 2013. International school exchanges in bilingual Geography teaching. In: K. Donert, P. Charzyński, Z. Podgórski (eds.), People in the move. Geography in European higher education. EUROGEO \& Association of Polish Adult Educators 17: 78-83.

Piotrowska I., 2014a. Okulografia w badaniach postrzegania i konstruowania wiedzy geograficznej. In: E. Szkurłat, A. Głowacz (eds.), Edukacja geograficzna na świecie i w Polsce - wybrane problemy. Prace Komisji Edukacji Geograficznej PTG 4: 175-189.

Piotrowska I., 2014b. Geografia jako dziedzina kształcenia opartego na uczniowskich projektach zintegrowanych. In: S. Dylak, G. Barabasz, D. Hejwosz-Gromkowska (eds.), Metoda projektów w edukacji ponadpodstawowej (na przykładzie przedmiotów przyrodniczych). UAM, OFEK, Samorząd Woj. Wielkopolskiego: 167-173.

Piotrowska I., 2015a. Edukacja w Wielkopolsce. Przeglad Wielkopolski 3: 58-64.

Piotrowska I., 2015b. Strategia uczenia się przez nauczanie (LDL) jako innowacja w edukacji przyrodniczej i pracy z uczniem zdolnym. In: M. Beczkiewicz, M. Szyszkiewicz-Golis (eds.), Ekologia Krajobrazu. Cz. 2. Przewodnik metodyczny. IBŚRiL, PAN, Poznań: 42-46.

Piotrowska I., 2015c. Uczeń zdolny w programie przedmiotu ekologia krajobrazu - "Nakładka” Akademia Talentów Przyrodniczych. In: M. Beczkiewicz, M. Szyszkiewicz-Golis (eds.), Ekologia Krajobrazu. Cz. 2. Przewodnik metodyczny. IBŚRiL, PAN, Poznań: 46-48.

Piotrowska I., 2016. Brain's GPS - not only for geographer. In: P. Charzyński, K. Donert, Z. Podgórski (eds.), Mapping the world - spatial skills in bilingual education. Geography in European higher education. EUROGEO \& SOP Oświatowiec 20: 167-177.

Piotrowska I., 2018a. Biogramy: Maria Czekańska. In: A. Jackowski, K. Krzemień, I. Sołjan (eds.), Geografowie polscy. Stownik biograficzny. IGiGP UJ, Kraków.

Piotrowska I., 2018b. Technologie geoinformacyjne w podstawie programowej - wyzwanie dla nauczyciela geografii. In: A. Hibszer, E. Szkurłat (eds.), Nauczyciel geografii wobec wyzwań reformowanej szkoty. Sosnowiec, Prace Komisji Edukacji Geograficznej PTG 8: 33-50.

Piotrowska I., Beczkiewicz M., 2013. Program nauczania przedmiotu dodatkowego dla szkót ponadgimnazjalnych. IBRiL PAN, WNGiG UAM, Poznań: 1-16.

Piotrowska I., Cichoń M., 2012. Wybrane stanowiska prezentujące dawny i obecny stan środowiska geograficznego doliny Warty i Ostrowa Tumskiego. In: D. Konieczka-Śliwińska, M. Herkt, R. Pernak (eds.), Dziedzictwo kulturowe Ostrowa Tumskiego w Poznaniu. Podręcznik dla nauczycieli i edukatorów. Centrum Turystyki Kulturowej TRAKT: $55-62$.

Piotrowska I., Cichoń M., 2015a. Dydaktyka geografii na Wydziale Nauk Geograficznych i Geologicznych UAM w Poznaniu. Przeglad Wielkopolski 3: 4-11.

Piotrowska I., Cichoń M., 2015b. Multimedia i e-podręczniki w kształceniu młodzieży pokolenia cyfrowego. In: A. Hibszer, E. Szkurłat (eds.) Technologie informacyjno-komunikacyjne w kształceniu geograficznym. Założenia teoretyczne. Diagnoza wykorzystania. Prace Komisji Edukacji Geograficznej PTG 4: 67-85.
Piotrowska I., Cichoń M., 2016a. Znaczenie stacji terenowych w kształtowaniu kompetencji naukowego badania środowiska geograficznego na różnych poziomach edukacji. In: A. Kostrzewski (ed.), Stacje naukowe Uniwersytetu im. Adama Mickiewicza w Poznaniu. Wydawnictwo Naukowe UAM, Poznań: 27-34.

Piotrowska I., Cichoń M., 2016b. Wybrane stanowiska prezentujące dawny i obecny stan środowiska geograficznego doliny Warty i Ostrowa Tumskiego. In: T. Stryjakiewicz (ed.), Ostrów Tumski w Poznaniu w perspektywie geograficznej. Wydawnictwo Naukowe UAM, Poznań, Seria Geografia 98: 59-72.

Piotrowska I., Hibszer A., Szkurłat E., Rachwał T., 2017. Podstawa programowa $\mathrm{z}$ geografii $\mathrm{w}$ szkole podstawowej. Komentarze i odpowiedzi do opinii nadesłanych w ramach konsultacji. Geografia w Szkole 2: 18-21.

Piotrowska I., Szkurłat E., 2016. Nowe problemy i metody badan procesu ksztatcenia geograficznego. Prace Komisji Edukacji Geograficznej PTG 6: 275.

Piróg D., Piróg S., 2007. Pożądane umiejętności absolwentów nauczycielskich studiów geograficznych na rynku pracy $\mathrm{w}$ procesie przemian społeczno-gospodarczych w Polsce. In: J. Lach, M. Borowiec, T. Rachwał (eds.), Procesy transformacji społeczno-gospodarczej i przyrodniczych struktur przestrzennych. Wyd. Naukowe AP, Kraków.

Polak M., 2014, Mobilna edukacja - jak wykorzystać potencjał edukacyjny nowoczesnych telefonów i tabletów. Online: www.slideshare.net/edunews/ mobilna-edukacja-jak-wykorzysta-potencja-edukacyjnynowoczesnych-telefonw-i-tabletw [accessed 2 January 2019].

Porter D.O., 2013. Co-Production and Network Structures in Public Education. In: V. Pestoff, T. Brandsen, B. Verschuere (eds.), New Public Governance, the Third Sector, and Co-Production. New York, Routledge: 145-168.

Rocard report, 2007. Science Education Now: A New Pedagogy for the Future of Europe. Online: www.eesc.europa.eu/ sites/default/files/resources/docs/rapportrocardfinal. pdf (accessed 10 January 2018).

Regulation [Rozporządzenie], 2010 Rozporządzenie Ministra Edukacji Narodowej z dnia 20 sierpnia 2010 r. zmieniające rozporządzenie $\mathrm{w}$ sprawie warunków i sposobu oceniania, klasyfikowania i promowania uczniów i słuchaczy oraz przeprowadzania sprawdzianów i egzaminów w szkołach publicznych. Dz.U. 2010 nr 156 poz. 1046.

Sławiński W., 2006. Dydaktyka biologii i ochrony środowiska. Wydawnictwo Naukowe PWN, Warszawa.

Spitzer M., 2011. Jak uczy się mózg. Wydawnictwo Naukowe PWN, Warszawa.

Stępniewska M., Abramowicz D., 2016. Społeczna percepcja i korzystanie ze świadczeń ekosystemowych miejskich terenów poeksploatacyjnych. Przykład Szacht w Poznaniu. Ekonomia i Środowisko 4(59): 252-262.

Sypniewski J., 2015a. Influence of the strategy of the Inquiry Based Science Education on the development of natural interests of students and acquiring natural-geographical competences in the course of extracurricular activities of natural science activity group. MA thesis, Adam Mickiewicz University, Poznań.

Sypniewski J., 2015b. Nauczanie przez odkrywanie odpowiedzia na wspótczesne wymagania w edukacji przyrodniczej. Przegląd Wielkopolski 109: 64-68.

Sypniewski J., 2017a. W roli akuszerki środowiska edukacyjnego. Geografia w Szkole 362,: 26-29. 
Sypniewski J., 2017b. Scenariusz zajęć z zastosowaniem strategii IBSE. Geografia w Szkole 362: 30-33.

Sypniewski J., 2018. Tam, gdzie nie sięga przestrzeń geograficzna. Kosmos w szkole, kosmos w podstawie? Prace Komisji Edukacji Geograficznej PTG 8: 169-180.

Szkurłat E., Hibszer A., Piotrowska I., Rachwał T., 2017a. Podstawa programowa przedmiotu geografia. II etap edukacyjny: klasy IV-VIII. In: Podstawa programowa ksztatcenia ogólnego z komentarzem; szkoła podstawowa geografia. Ośrodek Rozwoju Edukacji, Warszawa: 11-24.

Szkurłat E., Hibszer A., Piotrowska I., Rachwał T., 2017b. Komentarz do podstawy programowej geografia na II etapie edukacyjnym. In: Podstawa programowa ksztatcenia ogólnego z komentarzem; szkoła podstawowa geografia. Ośrodek Rozwoju Edukacji, Warszawa: 24-36.

Szkurłat E., Piotrowska I., 2018. GIS w nowej podstawie programowej geografii. Acta Universitatis Lodziensis, Folia Geographica Socio-Oeconomica., 34: 61-76.

Szkurłat E., Piotrowska I., Hibszer A., Rachwał T., Wieczorek T., 2017c. Nowa podstawa programowa z geografii dla liceum ogólnokształcącego oraz technikum - ogólne założenia i warunki realizacji. Geografia w Szkole 3: 26-31.

Szleper I., 2002. Ścieżka dydaktyczna Komprachcice-Ochodze. In: H. Paciej (ed.), Dziedzictwo kulturowe w regionie edukacja regionalna. Polskie Towarzystwo TurystycznoKrajoznawcze, Oddział Regionalny PTTK Śląska Opolskiego, Opole.
Tapscott D., 2009. Cyfrowa dorostość. Jak pokolenie sieci zmienia nasz świat. Online: dontapscott.com/books/grown-up-digital/ (accessed 28 October 2011).

Trna J., Trnová E., 2012. Inquiry-based Science Education Experiments. In: C. Bolte, J. Holbrook, F. Rauch (eds.), Inquiry-based Science Education in Europe: Reflections from the PROFILES Project. Berlin: Freie Universitat Berlin.

Van Uum M., Verhoeff R.P. \& Peters M., 2017. Inquiry-based science education: scaffolding pupils self-directed learning in open inquiry. International Journal of Science Education 39(18): 1-21.

Wójcicki M., 2018. Formy i zakres partycypacji społecznej w procesie planowania przestrzennego w Poznaniu. Bogucki Wydawnictwo Naukowe, Poznań.

Wojtkowicz Z., 1999. Aktywne metody w edukacji geograficznej. Stowarzyszenie Oświatowców Polskich, Toruń: 4-5.

Zwoliński Zb., 2009a. Rozwój myśli geoinformacyjnej. In: Zb. Zwoliński (ed.), GIS - platforma integracyjna geografii. Bogucki Wydawnictwo Naukowe, Poznań: 9-21.

Zwoliński Zb. (ed.), 2009b. GIS - platforma integracyjna geografii. Bogucki Wydawnictwo Naukowe, Poznań.

Zwoliński Zb., 2010. O homologiczności polskiej terminologii geoinformacyjnej. In: Zb. Zwoliński (ed.), GIS - woda $w$ środowisku. Bogucki Wydawnictwo Naukowe, Poznań: 21-30.

Żylińska M., 2013. Neurodydakyka. Nauczanie i uczenie się przyjazne mózgowi. Wydawnictwo Naukowe Uniwersytetu Mikołaja Kopernika, Torun. 